\title{
Methods for biomass stock estimation in Mediterranean maquis systems
}

\author{
Costantino Sirca ${ }^{(1-2)}$, Antonio \\ Caddeo $^{(1)}$, Donatella Spano ${ }^{(1-2)}$ \\ Valentina Bacciu ${ }^{(2)}$, Serena \\ Marras ${ }^{(1-2)}$
}

\begin{abstract}
As a result of Kyoto Protocol agreements, the scientific community increased its efforts to enhance the availability of biomass and organic carbon stock data in forest ecosystems. Nevertheless, a considerable data shortage has been recognized in estimating the stock of above-ground biomass (AGB) in Mediterranean maquis systems. This work aims at contributing in addressing such shortage by testing quick and non-disruptive methods to estimate the AGB stock in maquis species. Two methodologies were tested in three widespread sclerophyllous evergreen species (Pistacia lentiscus, Euphorbia dendroides, and Cystus monspeliensis). Both methodologies were based on the estimation of the apparent volume (AV): the first one assumed the shrub shape (or canopy) to be similar to a regular tridimensional solid, while the second method was based on plant digital images analysis. Results showed some differences in AV values estimated through the two methodologies, although a high correlation was found between them $\left(R^{2}=0.92-0.98\right)$ and with the AGB weight obtained from plant samples $\left(R^{2}=0.89-0.96\right)$. As a consequence, the shrubs apparent density values (i.e., weight/AV) vary depending on the method used for AV estimation. This should be taken into account when AV is used for AGB estimation. Besides, measurements of above-ground biomass were carried out to characterize the studied area. Results showed high variability in AGB values, ranging from 7.04 to $48.05 \mathrm{Mg} \mathrm{ha}^{-1}$ of dry matter.
\end{abstract} Keywords: Shrubland, Allometric Equations, Above Ground Biomass, Apparent
Volume tection, water and nutrients cycling, biodiversity, and pollution control) as well as in function of climate regulation. After the Kyoto protocol (KP), the role of shrub species was highlighted in 2005 during the Marrakech summit (Lumicisi et al. 2007); recently, the international challenges related to the carbon issue were renewed following the Doha agreements in 2012, when the KP objectives to pursue the reduction and constraint of greenhouse gases emission at global level were extended to 2020. New environmental policies and carbon market mechanisms are being developed in southern Europe (Boisgibault 2012), including the improvement of forest ability to sequester carbon with proper silvicultural practices (Corona \& Marchetti 2007) and fire management (Botequim et al. 2015, Corona et al. 2015). In
(1) DIPNET - Department of Science for Nature and Environmental Resources, University of Sassari, v. de Nicola 9, I-07100 Sassari (Italy); (2) Fondazione CMCC - Centro Euro-Mediterraneo sui Cambiamenti Climatici, Divisione IAFES, v. de Nicola 9, 07100 Sassari (Italy)

@ Costantino Sirca (cosirca@uniss.it)

Received: Jul 15, 2015 - Accepted: Apr 21, 2016

Citation: Sirca C, Caddeo A, Spano D, Bacciu V, Marras S (2016). Methods for biomass stock estimation in Mediterranean maquis systems. iForest 10: 108-114. - doi: 10.3832/ifor1769009 [online 2016-08-21]

Communicated by: Rupert Seidl most of these cases, the biomass stock assessment plays a key role (Barbati et al. 2007).

The "Good Practice Guidance for Land Use, Land Use Change and Forestry" (GPGLULUCF - Penman et al. 2003) is the official guide developed by the IPCC National Greenhouse Gas Inventories Programme to estimate the carbon stock and its changes in relation to the KP (Nabuurs et al. 2003, Schlamadinger et al. 2003). It defines five terrestrial carbon pools: above- and belowground biomass, dead wood, litter, and soil organic matter. In forestry systems, the above-ground biomass (AGB) stock and changes are mostly assessed through a combination of inventory data and the use of allometric equations that relate plant dendrometric measurements (trunk diameter at breast height, tree height, etc.) to the AGB weight. However, the application of the GPG-LULUCF protocols is difficult when Mediterranean maquis is involved. In such ecosystems, the quantification of the $A G B$ stock is challenging due to the high variability in species composition and because of the shrub architecture (Costa \& La Mantia 2005), which limits the application of traditional techniques developed for forestry tree species. As a consequence, there is still little information on the carbon stock capacity and changes in such ecosystems (Navarro Cerrillo \& Blanco Oyonarte 2006). This fact is particularly vexing in Italy, where the maquis ecosystem is one of the most represented forest categories (3.34\% 
of the national surface and $8.05 \%$ of forested area, with more than 1 million ha), denoting a critical issue in the context of the carbon credits market (Alisciani et al. 2011). In addition, the available $A G B$ data are also characterized by a wide range of variability and uncertainty; this has been demonstrated by recent efforts to harmonize, at international level, the allometric equations available for supporting volume and biomass assessment in tree/forestry systems (Somogyi et al. 2008, Henry et al. 2013).

Currently, different methods are used to estimate the $A G B$ in the maquis species. The destructive sampling method is accurate but time consuming and not always applicable (e.g., in protected areas - Gratani et al. 1980). Most used methods are based on allometric equations relating $A G B$ to its proxies, such as the shrub height (Gratani et al. 1980, Sternberg \& Shoshany 2001, Bianchi et al. 2002, Coomes et al. 2002, Scarton et al. 2002, Corona et al. 2011b) or the crown diameter (Gratani et al. 1980, Lledò et al. 1992, Quideau et al. 1998, Sternberg \& Shoshany 2001, Coomes et al. 2002, Ogaya et al. 2003, De Luis et al. 2004, Saglam et al. 2008, Corona et al. 2011a). Gratani et al. (1980) estimated the apparent volume (AV) from the crown diameter and height measurements, while Catarino et al. (1982) used plant height and stem diameter measurements. The shrub AV can be also used as a proxy of the AGB stock. Montès et al. (2000) proposed a computerized methodology to estimate the AV based on orthogonal-view digital images of the shrub. Other authors (Whittaker \& Woodwell 1968, Chapman 1986, Azmi et al. 1991, Usó et al. 1997, Sternberg \& Shoshany 2001, De Luis et al. 2006) developed a

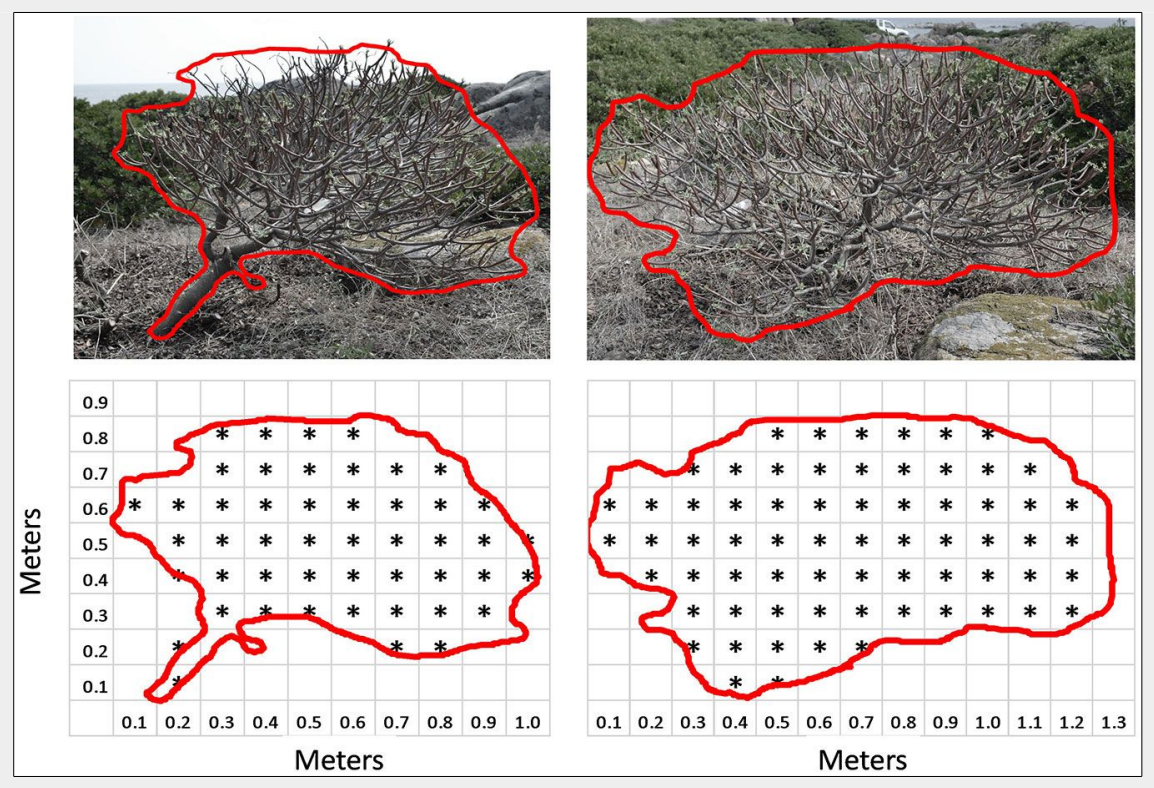

Fig. 1 - The apparent volume estimation with Methodology 2: digital photos and contouring (upper panels); a view of Excel worksheet for the volume calculation (lower panels). The apparent volume of the shrub is obtained summing the volume of each layer of $0.1 \mathrm{~m}$ height.

methodology where the AV is estimated assuming the shrub shape to be similar to a 3D regular solid (i.e., cylinder, sphere, rotation paraboloid, etc.). In all cited cases, reliable data on the specific apparent density of the shrub (i.e., weight/AV, $\mathrm{kg} \mathrm{m}^{-3}$ ) are needed.

Chirici et al. (2009) and Bacciu (2009) applied an expeditious method to estimate a "volume index" as the product between the vegetation coverage degree and shrub height, while in recent years a growing interest was addressed to the application of the Light Detection And Ranging (LiDAR) systems which estimates the AGB stock from the relationship between plant weight and canopy height or volume (Garcìa et al. 2010, Maselli et al. 2011, Corona et al. 2012).

The aim of this paper is to contribute in evaluating methodologies able to estimate the AGB stock in Mediterranean maquis systems. In particular, this work explores the potential application of two expeditious and non-disruptive methodologies to be applied for three of the most representative maquis species of the Mediterranean basin: Pistacia lentiscus L., Cystus monspeliensis L. and Euphorbia dendroides L. Additional measurements of $A G B$ were carried out in order to characterize the study area and to evaluate the two applied methodologies, thus increasing the availability of such data within the scientific community.

\section{Materials and methods}

\section{Study site}

The work was carried out in Sardinia (Italy), the second largest island (24090 $\mathrm{km}^{2}$ ) of the Mediterranean Sea, where approximately half of the land surface is 
obtained through the sum of each layer's volume.

The sampled shrubs were cut and ovendried in a laboratory at $65{ }^{\circ} \mathrm{C}$ to obtain the dry weight.

The regressions between the AV estimated with the two methodologies and the dry weight were then calculated for each species. The $A D$ values (dry weight/AV ratio) for each species were also obtained both with Methodology 1 and 2.

\section{Field measurements: AGB stock} estimation

The findings of the above analysis were applied to a case study. Three areas characterized by a different degree of soil cover and mean shrubs height (identified as low, medium, and high recolonization degree) were identified on the Asinara Island. In each area, three plots of $3.0 \times 3.0 \mathrm{~m}$ were demarcated, where sub-plots of $0.5 \times 0.5 \mathrm{~m}$ were further delimited. In each sub-plot and for each species, the basal area and the canopy height were measured (at $0.1 \times$ $0.1 \mathrm{~m}$ points) to estimate the $A V$ as the product of specific soil cover and plant height. This method was chosen since shrubs were highly intermingled. Given the small size of the sub-plots, it was assumed that the estimated $\mathrm{AV}$ for each plot was comparable to the AV of the single shrubs obtained with Methodology 2. Finally, the $A G B$ was estimated by the product of the $A V$ and the AD obtained from the Methodology 2.

In order to better characterize the site, the litter and dead wood stock were also calculated. Ten aluminum frames of $0.1 \times$ $0.1 \mathrm{~m}$ were randomly distributed in each plot to estimate the litter amount, and all the dead wood material inside each plot was collected. Both litter samples and dead wood were oven-dried $\left(65^{\circ} \mathrm{C}\right)$ and then weighed in the laboratory.

\section{Results and discussion}

Application of two methodologies for above-ground biomass estimation

The main attributes of the sampled shrubs are reported in Tab. 1. The lowest and highest mean height was found in $C$. monspeliensis and $E$. dendroides, respectively, while $P$. lentiscus showed the mean
Tab. 1 - Attributes of the sampled plants. (MD): maximum crown diameter; (OMD): diameter orthogonal to MD; (AV): apparent volume; (AD): apparent density.

\begin{tabular}{|c|c|c|c|c|}
\hline Parameter & Statistics & $\begin{array}{l}\text { C. monspeliensis } \\
(\mathrm{n}=18)\end{array}$ & $\begin{array}{l}\text { E. dendroides } \\
(n=12)\end{array}$ & $\begin{array}{l}\text { P. lentiscus } \\
(\mathrm{n}=8)\end{array}$ \\
\hline \multirow[t]{4}{*}{ Height (m) } & average & 0.763 & 1.453 & 1.203 \\
\hline & maximum & 1.200 & 2.200 & 1.800 \\
\hline & minimum & 0.340 & 0.730 & 0.480 \\
\hline & standard dev. & 0.277 & 0.489 & 0.475 \\
\hline \multirow[t]{4}{*}{$M D(m)$} & average & 0.999 & 1.653 & 2.406 \\
\hline & maximum & 1.530 & 2.400 & 3.000 \\
\hline & minimum & 0.310 & 0.800 & 1.930 \\
\hline & standard dev. & 0.357 & 0.599 & 0.299 \\
\hline \multirow[t]{4}{*}{ OMD (m) } & average & 0.804 & 1.664 & 2.088 \\
\hline & maximum & 1.400 & 2.620 & 3.100 \\
\hline & minimum & 0.270 & 0.650 & 1.640 \\
\hline & standard dev. & 0.302 & 0.610 & 0.606 \\
\hline $\mathrm{AV}\left(\mathrm{m}^{3}\right)$ & average & 0.43 & 2.80 & 3.32 \\
\hline \multirow[t]{3}{*}{ Methodology 1} & maximum & 1.04 & 7.21 & 6.53 \\
\hline & minimum & 0.02 & 0.20 & 0.86 \\
\hline & standard dev. & 0.33 & 2.42 & 2.04 \\
\hline $\mathrm{AV}\left(\mathrm{m}^{3}\right)$ & average & 0.26 & 1.59 & 2.63 \\
\hline \multirow[t]{3}{*}{ Methodology 2} & maximum & 0.60 & 5.10 & 4.90 \\
\hline & minimum & 0.01 & 0.06 & 0.71 \\
\hline & standard dev. & 0.21 & 1.65 & 1.61 \\
\hline \multirow[t]{4}{*}{ Dry weight (kg) } & average & 0.68 & 5.25 & 8.85 \\
\hline & maximum & 1.48 & 15.16 & 13.77 \\
\hline & minimum & 0.12 & 0.31 & 3.39 \\
\hline & standard dev. & 0.45 & 5.35 & 4.13 \\
\hline AD (kg d.m. $\left.\mathrm{m}^{-3}\right)$ & average & 2.18 & 1.67 & 3.02 \\
\hline \multirow[t]{3}{*}{ Methodology 1} & maximum & 7.95 & 2.66 & 4.74 \\
\hline & minimum & 1.20 & 0.86 & 2.08 \\
\hline & standard dev. & 1.60 & 0.59 & 0.98 \\
\hline $\mathrm{AD}\left(\mathrm{kg} \mathrm{d} . \mathrm{m} . \mathrm{m}^{-3}\right)$ & average & 4.04 & 3.44 & 3.81 \\
\hline \multirow[t]{3}{*}{ Methodology 2} & maximum & 15.00 & 4.84 & 5.76 \\
\hline & minimum & 1.79 & 2.34 & 2.77 \\
\hline & standard dev. & 3.13 & 0.87 & 1.06 \\
\hline
\end{tabular}

highest crown diameters. C. monspeliensis and $P$. lentiscus showed the lowest and highest mean dry weight and AV per shrub, estimated with both Methodology 1 and 2.

Differences in the AV depend not only on the methodology used for its estimation but also on the species. In this analysis, higher differences were found for C. monspeliensis (62\%) and E. dendroides (60\%) than for P. lentiscus (26\%), mainly due to the more irregular crown contour of the first two species with respect to $P$. lentiscus.

Results also confirm that the method used for the AV estimation should be appropriately considered when AD values are used, since the two terms are strictly related. In Methodology 1 the shrub shape is assumed to be regular (i.e., the plant contour irregularities are not considered), while in Methodology 2 the canopy contour is more detailed. Consequently, AVs calculated with Methodology 1 show higher values than those obtained by Methodology 2 (Tab. 1). This result highlights the importance to have specific AV$A G B$ relationships for a reliable biomass stock assessment.

Results from the two methodologies were compared and a strong relationship between the AV estimated with Methodology 1 and $2\left(R^{2}=0.95-0.98-\right.$ Fig. 2$)$ was

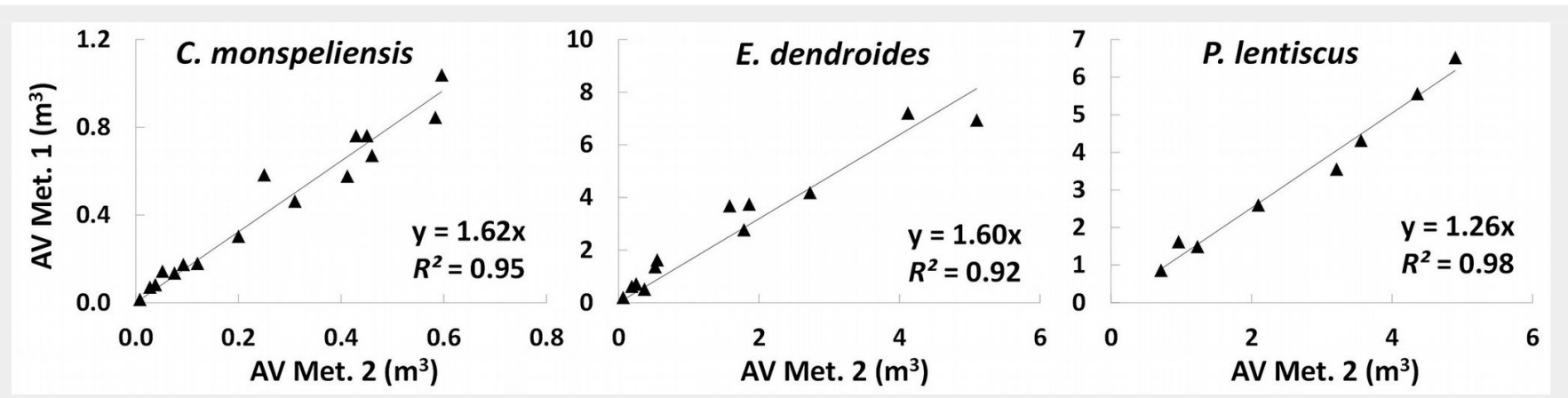

Fig. 2 - Relationships between the apparent volume (AV) estimated with Methodology 1 (Met.1) and Methodology 2 (Met. 2). 


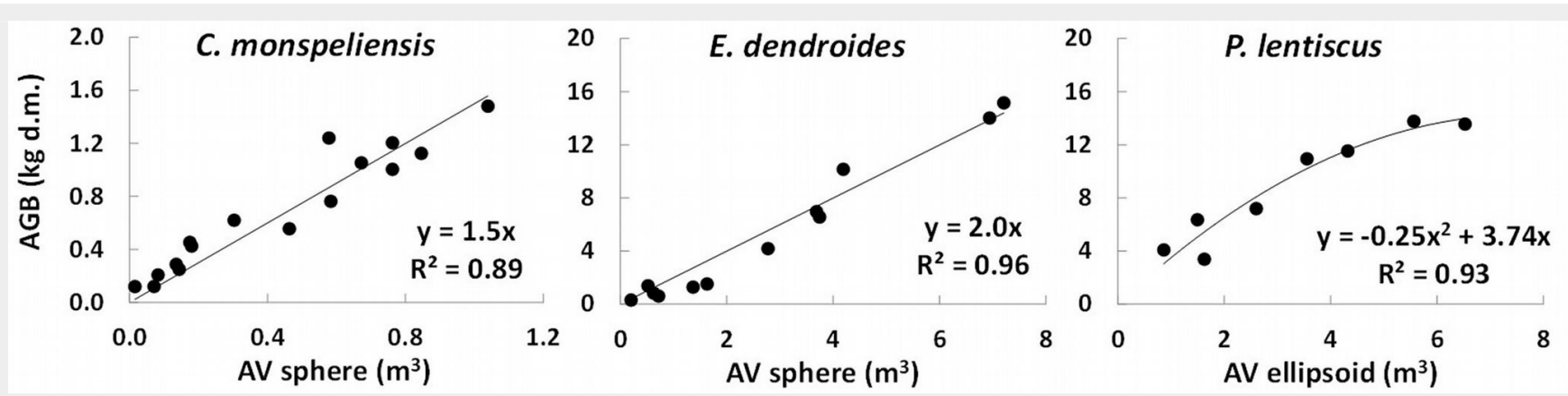

Fig. 3 - Relationships between the apparent volume (AV) estimated with Methodology 1 and the above-ground biomass (AGB).

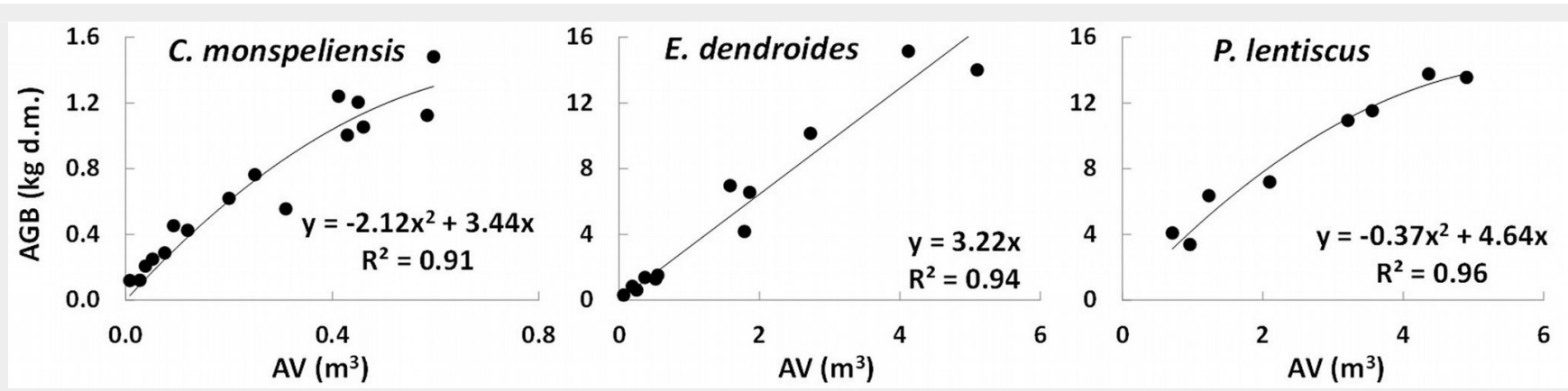

Fig. 4 - Relationships between the apparent volume (AV) estimated with Methodology 2 and the above-ground biomass (AGB).

found. This confirms that reliable AGB assessments based on AV estimates can be obtained both with Methodology 1 and 2, when appropriate $A D$ values are used.

The corresponding AD values for Methodology 1 and 2 are reported in Tab. 1. The AV estimation methodology also affects the distribution of the apparent density values between species. Higher $A D$ values for each species were found when $A V$ was obtained with Methodology 2 (Cystus $+85.3 \%$, Euphorbia $+106.0 \%$, Pistacia $+26.2 \%$ ). With Methodology 1 , the highest mean AD value was found for $P$. lentiscus, followed by $C$. monspeliensis, but the opposite was obtained using Methodology 2. The lowest mean $A D$ value was obtained for $E$. dendroides with both methodologies.

Furthermore, simple relationships between the estimated $A V$ and the dry weight of the sampled plants were calculated. The $R^{2}$ value ranged from 0.89 to
0.96 (Fig. 3) with Methodology 1 (AV estimated as $3 \mathrm{D}$ shape) and the best $3 \mathrm{D}$ shape (higher $R^{2}$ value) is different depending on the species (sphere for C. monspeliensis and $E$. dendroides, and ellipsoid for P.lentiscus). Comparable $R^{2}$ values between species were indeed obtained when AV was estimated with Methodology $2\left(R^{2}=0.91\right.$ 0.96 - Fig. 4).

Previous studies did apply similar methods to maquis species. Gratani et al. (1980) obtained a $R^{2}$ value of 0.85 for $P$. lentiscus by estimating the $A V$ as $D^{2} \cdot H$ (D: diameter, $\mathrm{H}$ : height). Usó et al. (1997) did not find statistical differences in using the circular cylinder, elliptical cylinder, and paraboloid of rotation as proxies of the AGB stock in Cistus albidus, Thymus vulgaris, and Rosmarinus officinalis. A similar approach was used in a study conducted in arid sites in Israel, where Sternberg \& Shoshany (2001) calculated the AV for more than 20 shrub species using the formula of several solids (as inverted cone, spheroid, cylinder, etc.). However, no indication about the solid shape showing the best fit with the $A G B$ stock values was reported by the authors. Our results confirmed that $A V$ can be used as a proxy of the $A G B$ weight with quick field measurements, but providing appropriate AV-AGB relationships is crucial. Although this analysis was based on a limited number of samples, results are promising also in view of the growing interest on proximal sensing techniques (e.g., LiDAR) for the AGB assessment.

\section{Field measurements: $A G B$ stock}

estimation

Previous results were applied for estimating the AGB in the same area, with the aim of increasing the limited availability of AGB data in maquis systems within the scientific community. Tab. 2 shows the structural

Tab. 2 - Main structural characteristics of the sampled areas. (AV): apparent volume; (AGB): above-ground biomass); (*): the soil cover is above $100 \%$ due to the partial overlapping of the species.

\begin{tabular}{|c|c|c|c|c|c|c|c|}
\hline \multirow{2}{*}{$\begin{array}{l}\text { Recolonization } \\
\text { degree }\end{array}$} & \multirow{2}{*}{ Species } & \multirow{2}{*}{$\begin{array}{l}\text { Cover* } \\
\text { (\%) }\end{array}$} & \multirow{2}{*}{$\begin{array}{c}\mathrm{AV} \\
\left(\mathrm{m}^{3} \mathrm{~m}^{-2}\right)\end{array}$} & \multicolumn{3}{|c|}{ Height (m) } & \multirow{2}{*}{$\begin{array}{c}\text { AGB } \\
\left(\mathrm{Mg} \mathrm{d.m.} \mathrm{ha}^{-1}\right)\end{array}$} \\
\hline & & & & mean & $\max$ & $\min$ & \\
\hline \multirow[t]{3}{*}{ low } & C. monspeliensis & 32.9 & 0.104 & 0.27 & 0.50 & 0.08 & 4.209 \\
\hline & P. lentiscus & 22.7 & 0.074 & 0.27 & 0.55 & 0.10 & 2.830 \\
\hline & baresoil & 44.7 & - & - & - & - & - \\
\hline \multirow[t]{3}{*}{ medium } & E. dendroides & 8.9 & 0.082 & 0.75 & 1.30 & 0.38 & 2.832 \\
\hline & P. lentiscus & 69.5 & 0.332 & 0.43 & 0.80 & 0.10 & 12.644 \\
\hline & baresoil & 25.1 & - & - & - & - & - \\
\hline \multirow{3}{*}{ high } & E. dendroides & 43.7 & 0.833 & 1.34 & 1.80 & 0.80 & 28.636 \\
\hline & P. lentiscus & 49.4 & 0.460 & 0.76 & 1.75 & 0.25 & 17.506 \\
\hline & baresoil & 13.9 & - & - & - & - & - \\
\hline
\end{tabular}


Tab. 3 - Above-ground biomass (AGB), litter and dead wood stock (Mg d.m. ha ${ }^{-1}$ ) of the sampled areas.

\begin{tabular}{lrccc}
\hline $\begin{array}{l}\text { Recolonization } \\
\text { degree }\end{array}$ & AGB & Litter & $\begin{array}{l}\text { Dead } \\
\text { wood }\end{array}$ & Total \\
\hline low & 7.04 & 21.18 & 3.46 & 31.68 \\
medium & 15.48 & 23.48 & 1.36 & 40.32 \\
high & 48.05 & 19.88 & 1.24 & 69.17 \\
Average & 23.52 & 21.51 & 2.02 & 47.06 \\
\hline
\end{tabular}

characteristics of the areas where the woody stocks were estimated. On average, the AV ranged from $0.18 \mathrm{~m}^{3} \mathrm{~m}^{-2}$ to $1.34 \mathrm{~m}^{3}$ $\mathrm{m}^{-2}$ from low to high recolonization degree sites. The AGB of C. monspeliensis inversely decreased with respect to the recolonization degree (Tab. 2), with values ranging from 1.91 to $4.21 \mathrm{Mg} \mathrm{d.m.} \mathrm{ha-1.} \mathrm{An} \mathrm{opposite}$ trend was observed both for $P$. lentiscus (2.83-17.51 Mg d.m. ha ${ }^{-1}$ ) and E. dendroides (2.83-28.64 Mg d.m. ha-1), whose AGB values increased from low to high recolonization degree. These results are in accordance with the patterns of vegetation dynamics related to secondary succession models (also conceptualized as vegetation series - Farris \& Filigheddu 2011), already described for north-western Sardinia (Biondi et al. 2001) and for the Asinara National Park (Farris et al. 2007, 2010, Bacchetta et al. 2009, Pisanu et al. 2014). Due to these succession dynamics, and to the consequent species distribution and structure, the AGB ranged from 7.04 (low recolonization degree) to $48.05 \mathrm{Mg}$ d.m. ha ${ }^{-1}$ (high recolonization degree - Tab. 3).

Results were also compared with findings from a literature survey, even if this comparison may be affected by a certain degree of uncertainty due to different reasons: the reduced size of the surveyed area, the low number of replicates in our analysis, and the high variability in species, structural characteristics, and methodologies used in different studies. Only a few papers reported results related to a single species. For $P$. lentiscus, Gratani et al. (1980) found an AGB value ranging from 0.90 to $2.17 \mathrm{Mg} \mathrm{d.m}$. ha ${ }^{-1}$, while Peressotti et al. (1999) reported a value of $1.30 \mathrm{Mg}$ d.m. ha ${ }^{-1}$, lower than our findings. More similar results were reported for $P$. lentiscus (19.67 Mg d.m. ha-1 - Navarro Cerrillo \& Blanco Oyonarte 2006; 5.80 to $9 \mathrm{Mg}$ d.m. ha $^{-1}$ - Corona et al. 2011b). For E. dendroides, Corona et al. (2011b) reported a value ranging from 3.60 to $11.30 \mathrm{Mg}$ d.m. ha ${ }^{-1}$.

Less marked differences within the investigated areas were observed for the litter and dead woody material. In particular, the litter load ranged from 19.9 to $23.5 \mathrm{Mg}$ d.m. ha $^{-1}$. In Greece, Dimitrakopoulos (2002) found that the average litter load in an evergreen-sclerophyllous shrubland, with height up to $1.5 \mathrm{~m}$, was $2.51 \mathrm{Mg} \mathrm{d} . \mathrm{m}$. ha", and slightly higher (3.38 Mg d.m. ha ${ }^{-1}$ ) in the same vegetation with height up to $3 \mathrm{~m}$. In California, Countryman (1982) collected dry weight of litter ranging from 6.77 to
49.60 Mg d.m. ha-1. These extreme differences are not only related to different structural and vegetation characteristics, but also to sampling methodologies: according to Countryman (1982) litter included all dead organic material above the mineral soil in the surface layer, whereas Dimitrakopoulos (2002) supposedly considered only the freshly fallen leaves and spines. In our sampled areas, the dead woody material load was relatively low compared with AGB and litter, and it decreased from low to highly recolonized plots. This fact is partially due to the grazing pressure (mainly by horses and goats), causing mechanical damages to the Cystus vegetation in low recolonized areas. Overall, the sum of living and dead mass ranged from 31.68 to $69.17 \mathrm{Mg}$ d.m. ha-1 from low to high recolonization degree (Tab. 3 ).

\section{Conclusions}

Consistent and wider datasets of carbon stock in Mediterranean forests are essential for studies related to nutrient cycles, ecology, global change impact assessment, and for management purposes. This is a critical issue especially for Mediterranean maquis systems, where the quantification of the above-ground biomass is challenging. Our results showed that expeditious measurements of the apparent canopy volume can be used for assessing the aboveground biomass of these ecosystems. The two applied methodologies performed well in estimating AV. Results showed that the apparent canopy density values depend on the methodologies used for the apparent volume estimation. In addition, the combination of data related to shrubs volume and density can be of great help in other studies where plant volume assessment is made using different methods (e.g., LiDAR scanner).

This study confirms the high degree of heterogeneity of these systems, and highlights that species and applied methodologies are factors that should be taken into account in order to generalize the results from different studies. Moreover, it provides AGB data and equations for AGB estimation in three widespread shrub species, thus contributing to enhance the limited datasets and information for these ecosystems.

This work was partially funded by the research project MIUR PRIN: CARBOTREES

\section{Acknowledgements}

- Climate change mitigation strategies in tree crops and forestry in Italy (2013-2016, Project Coordinator: Prof. Riccardo Valentini).

\section{References}

Alisciani F, Carbone F, Perugini L (2011). Critical issues and challenges in the post-2012 perspective for the possible participation of the forestry sector market for carbon credits. Forest@ 8: 149-161. [in Italian with English abstract] - doi: 10.3832/eforo672-008

Azmi M, Razali W, Mohd W, Fauzidah A (1991). Characteristics and volume-weight relationship of four Malaysian bamboos. Journal of Tropical Forest Science 4 (1): 87-93.

Bacchetta G, Bagella S, Biondi E, Farris E, Filigheddu R, Mossa L (2009). Vegetazione forestale e serie di vegetazione della Sardegna (con rappresentazione cartografica alla scala 1:350.000) [Forestry vegetation and vegetation series of Sardinia (with 1: 350.000 maps cartography)]. Fitosociologia 46 (1) suppl 1: $3-82$. [in Italian] [online] URL: http://eprints.uniss.it/35 441

Bacciu VM (2009). Maquis fuel model development to support spatially-explicit fire modeling applications. PhD Thesis, Dipartimento di Economia e Sistemi Arborei, Università degli Studi di Sassari, Sassari, Italy, pp. 263. [online] URL: http://eprints.uniss.it/109o/

Barbati A, Corona P, Marchetti M (2007). A forest typology for monitoring sustainable forest management: the case of European forest types. Plant Biosystems 141 (1): 93-103. - doi: 10.1080/11263500601153842

Bianchi L, Calamini G, Gregori E, Paci M, Pallanza S, Pierguidi A, Salbitano F, Tani A, Vedele S (2002). Valutazione degli effetti del rimboschimento in zone aride della Sardegna: risultati preliminari sulla vegetazione [Evaluation of the reforestation effects on arid areas of Sardinia: preliminary results on the vegetation]. L'Italia Forestale e Montana 4: 353-368. [in Italian] Biondi E, Filigheddu R, Farris E (2001). II paesaggio vegetale della Nurra [The Nurra landscape]. Fitosociologia 38 (2) Suppl. 2: 3-105. [in Italian] [online] URL: http://eprints.uniss.it/3178/ Boisgibault L (2012). Carbon constraint in the Mediterranean: differentiated impacts and policies for carbon reduction in the Euro-Mediterranean region. IPEMED Report, IPEMED, Paris, France, pp. 56. [online] URL: http://papers. ssrn.com/sol3/papers.cfm?abstract id $=2385175$ Botequim B, Zubizarreta-Gerendiain A, GarciaGonzalo J, Silva A, Marques S, Fernandes PM, Pereira JMC, Tomé M (2015). A model of shrub biomass accumulation as a tool to support management of Portuguese forests. iForest 8: 114-125. - doi: 10.3832/iforog31-008

Catarino FM, Correia OCA, Correia AIVD (1982). Structure and dynamics of Serra da Arràbida mediterranean vegetation. Ecologia Mediterranea 8 (1/2): 203-222.

Chapman SB (1986). Production ecology and nutrient budgets. In: "Methods in Plant Ecology" (Moore PD, Chapman SB eds). Blackwell Scientific Publications, Oxford, UK, pp. 1-559. Chirici G, Oriani A, Tognetti R, Garfi V, Chiavetta U, Lasserre B, Marchetti M (2009). Experimental testing of a volume index as a fast method 
for estimating carbon stock in the understorey vegetation. Forest@6: 154-16o. [in Italian with English abstract] - doi: 10.3832/eforo577-006 Coomes DA, Allen RB, Scott NA, Goulding C, Beets $P$ (2002). Designing systems to monitor carbon stocks in forests and shrublands. Forest Ecology and Management 164: 89-108. - doi: 10.1016/S0378-1127(01)00592-8

Corona P, Marchetti M (2007). Outlining multipurpose forest inventories to assess the ecosystem approach in forestry. Plant Biosystems 141: 243-251. - doi: 10.1080/11263500701401836 Corona P, Chirici G, McRoberts RE, Winter S, Barbati A (2011a). Contribution of large-scale forest inventories to biodiversity assessment and monitoring. Forest Ecology and Management 262: 2061-2069. - doi: 10.1016/j.foreco.2011.08. 044

Corona P, Pasta S, Giardina G, La Mantia T (2011b). Assessing the biomass of shrubs typical of Mediterranean pre-forest communities. Plant Biosystems 146 (2): 252-257. - doi: 10.1080/ 11263504.2011.593200

Corona P, Cartisano R, Salvati R, Chirici G, Floris A, Di Martino P, Marchetti M, Scrinzi G, Clementel F, Travaglini D, Torresan C (2012). Airborne Laser Scanning to support forest resource management under alpine, temperate and Mediterranean environments in Italy. European Journal of Remote Sensing 45: 27-37. - doi: 10.5721/EuJRS20124503

Corona P, Ascoli D, Barbati A, Bovio G, Colangelo G, Elia M, Garfì V, lovino F, Lafortezza R, Leone V, Lovreglio R, Marchetti M, Marchi E, Menguzzato G, Nocentini S, Picchio R, Portoghesi L, Puletti N, Sanesi G, Chianucci F (2015). Integrated forest management to prevent wildfires under Mediterranean environments. Annals of Silvicultural Research 39 (1): 1-22. [online] URL: http://dspace.unitus.it/handle/2067/2668

Costa G, La Mantia T (2005). The role of the Mediterranean maquis in carbon sequestration. Forest@ 2: 378-387. [in Italian with English abstract] - doi: 10.3832/eforo319-0020378

Countryman CM (1982). Physical characteristics of some Northern California brush fuels. General Technical Report PSW-61, Pacific Southwest Forest and Range Experiment Station, USDA Forest Service, Berkeley, CA, USA, pp. 12. [online] URL: http://www.treesearch.fs.fed.us/ pubs $/ 27008$

De Luis M, Baeza MJ, Raventos J, GonzalezHidalgo JC (2004). Fuel characteristics and fire behaviour in mature Mediterranean gorse shrublands. International Journal of Wildland Fire 13: 79-87. - doi: 10.1071/WF03005

De Luis M, Raventos J, Gonzalez-Hidalgo JC (2006). Post-fire vegetation succession in Mediterranean gorse shrublands. Acta Oecologica 30: 54-61. - doi: 10.1016/j.actao.2006.01.005

Dimitrakopoulos AP (2002). Mediterranean fuel models and potential fire behaviour in Greece. International Journal of Wildland Fire 11: 127130. - doi: 10.1071/WF02018

Farris E, Filigheddu R (2011). Patterns of plant population spatial variability in relation to vegetation dynamics: vegetation series matter. Fitosociologia 48 (1) suppl 1: 67-80. [online] URL: http://s3.amazonaws.com/academia.edu. documents/31052924

Farris E, Secchi Z, Filigheddu R (2007). Phytosoci- ological study of the shrub and pre-forest communities of the effusive substrata of NW Sardinia. Fitosociologia 44 (2): 55-81. [online] URL: http://eprints.uniss.it/3119/

Farris E, Filibeck G, Marignani M, Rosati L (2010). The power of potential natural vegetation (and of spatial-temporal scale) - a response to Carrión and Fernández (2009). Journal of Biogeography 37: 2211-2213. - doi: 10.1111/j.1365-2699.20 10.02323.x

Forteleoni C, Gazale V (2008). Asinara. Parco Nazionale - Area Marina Protetta [Asinara. National Park - Marine Reserve]. Carlo Delfino Editore, Sassari, Italy, pp. 252. [in Italian]

Garcìa M, Riaño D, Chuvieco E, Danson FM (2010). Estimating biomass carbon stocks for a Mediterranean forest in central Spain using LiDAR height and intensity data. Remote Sensing of Environment 114 (4): 816-830. - doi: 10.1016/j.rse.2009.11.021

Gratani L, Amadori M, Veri L, Bruno F, Porri M (1980). Determinazione di un metodo di stima della biomassa nella macchia di Castelporziano (Lazio) [Assessment of a method for estimating the biomass in the maquis of Castelporziano (Lazio)]. Annali di Botanica 41 (1): 131-151. [in Italian]

Henry M, Bombelli A, Trotta C, Alessandrini A, Sola G, Vieilledent $G$, Santenoise P, Longuetaud F, Valentini R, Picard N, Saint-André L (2013). GlobAllomeTree: international platform for tree allometric equations to support volume, biomass and carbon assessment. iForest 6: 326330. - doi: 10.3832/iforo901-006

Lledò MJ, Sanchez JR, Bellot J, Boronat J, Ibanez JJ, Escarré A (1992). Structure, biomass and production of a resprouted holm-oak (Quercus ilex L.) forest in NE Spain. Vegetatio 99-100: 5159. - doi: 10.1007/BFo0118209

Lumicisi A, Tedeschi V, Vitullo M, Federici S, Pompei $E$ (2007). The role of central, regional and local administrations in the application of the Kyoto protocol in the forestry sector in Italy. Forest@ 4 (3): 246-249. [in Italian with English abstract] - doi: 10.3832/eforo466-004

Maselli F, Chiesi M, Montaghi A, Pranzini E (2011). Use of ETM+ images to extend stem volume estimates obtained from LiDAR data. ISPRS Journal of Photogrammetry and Remote Sensing 66 (5): 662-671. - doi: 10.1016/j.isprsjprs. 2011.04.007

Montès N, Gauquelin T, Badri W, Bertaudiere V, Zaoui El H (2000). A nondestructive method for estimating aboveground forest biomass in threatened woodlands. Forest Ecology and Management 130: 37-46. - doi: 10.1016/S03781127(99)00188-7

Nabuurs GJ, Schelhaas MJ, Mohren MJ, Field CB (2003). Temporal evolution of the European forest sector carbon sink from 1950 to 1999. Global Change Biology 9: 152-160. - doi: 10.1046/ j.1365-2486.2003.00570.x

Navarro Cerrillo RM, Blanco Oyonarte P (2006). Estimation of aboveground biomass in shrubland ecosystem of southern Spain. Investigaciones Agrarias: Sistemas y Recursos Forestales 15 (2): 197-207. - doi: 10.5424/srf/2006152-00964 Ogaya R, Penuelas J, Martinez-Vilalta J, Mangiron $M$ (2003). Effect of drought on diameter increment of Quercus ilex, Phillyrea latifolia, and Arbutus unedo in a holm oak forest of NE Spain.
Forest Ecology and Management 180: 175-184. doi: 10.1016/S0378-1127(02)00598-4

Penman J, Gytarsky M, Hiraushi T, Krug T, Kruger D, Pipatti R, Buendia L, Miwa K, Ngara T, Tanabe K, Wagner F (2003). LUCF Sector good practice guidance - Chapter 3: Annex 3A.1 Biomass Default Tables for Section 3.2: Forest land good practice guidance for land use. Landuse change and forestry. IGES/IPCC, Hayama, Kanagawa, Japan, pp. 359-405.

Peressotti A, Asunis C, Cesaraccio C (1999). Stima indiretta della biomassa e della copertura vegetale di un ecosistema mediterraneo a macchia: il caso della riserva naturale integrale Arca di Noè [Indirect estimation of the biomass and ground cover in a Mediterranean maquis ecosystem: the case study of Arca di Noè Park]. In: "Monitoraggio di un ecosistema a macchia mediterranea: misure ecofisiologiche e micrometeorologiche" (Benincasa F, Cristoferi G, Maracchi $G$, Tedeschi $P$ eds). Collana Tecnico Scientifica INAPA, Quaderno 6, INAPA, Firenze, Italy, pp. 79-86. [in Italian]

Pisanu S, Farris E, Caria MC, Filigheddu R, Urbani M, Bagella S (2014). Vegetation and plant landscape of Asinara National Park (Italy). Plant Sociology 51: 31-57. [online] URL: http://eprints. uniss.it/10260/

Quideau SA, Graham RC, Chadwick OA, Wood HB (1998). Organic carbon sequestration under chaparral and pine after four decades of soil development. Geoderma 83: 227-242. - doi: 10.1016/So016-7061(97)00142-0

Rühl J, Pasta S, La Mantia T (2005). A method for the study of secondary succession processes in terraced old fields: the case study Pantelleria Island (Canale di Sicilia). Forest@ 2 (4): 388398. [in Italian with English abstract] - doi: 10.3832/eforo324-0020388

Saglam B, Bilgili E, Kucuk O, Dinç Durmaz B (2008). Fire behavior in Mediterranean shrub species (Maquis). African Journal of Biotechnology 7 (22): 4122-4129. [online] URL: http:// www.ajol.info/index.php/ajb/article/view/59536 Scarton F, Day JW, Rismondo A (2002). Primary production and decomposition of Sarcocornia fruticosa (L.) Scott and Phragmites australis Trin. Ex Steudel in the Po Delta, Italy. Estuaries 25: 325-336. - doi: 10.1007/BF02695977

Schlamadinger B, Boonpragob K, Janzen H, Kurz W, Lasco R, Smith P, Collas P, Abdalla El Siddig EN, Fischlin A, Matsumoto $M$, Nakhutin $A$, Noble I, Pignard G, Somogyi Z, Zhang XQ (2003). Supplementary methods and good practice guidance arising from the Kyoto protocol. In: "Good Practice Guidance for Land Use, Land-Use Change and Forestry" (Penman J, Gytarsky M, Hiraishi T, Krug T, Kruger D, Pipatti R, Buendia L, Miwa K, Ngara T, Tanabe K, Wagner $F$ eds). IGES/IPCC, Hayama, Kanagawa, Japan, pp. 359-405.

Somogyi Z, Teobaldelli M, Federici S, Matteucci G, Pagliari V, Grassi G, Seufert G (2008). Allometric biomass and carbon factors database. iForest 1: 107-113. - doi: 10.3832/iforo463-00101 07

Sternberg M, Shoshany M (2001). Influence of slope aspect on Mediterranean woody formations: comparison of a semiarid and an arid site in Israel. Ecological Research 16: 335-345. - doi: 10.1046/j.1440-1703.2001.00393.x 
Usó JL, Mateu J, Karjalainen T, Salvador P (1997). Allometric regression equations to determine

aerial biomasses of Mediterranean shrubs. Whittaker RH, Woodwell GM (1968). Dimension and production relations of trees and shrubs in the Brookhaven Forest, New York. Ecology 56: 1-25. - doi: $10.2307 / 2258063$ 